\title{
Modeling Information Linkages in the Stock and Options Markets
}

\author{
K.Y. Ho ${ }^{\mathrm{a}}$, L. Zheng ${ }^{\mathrm{b}}$ and Z.Y. Zhang \\ ${ }^{a}$ College of Business and Economics, Australian National University, Australia \\ ${ }^{b}$ Department of Economics, City College of New York, U.S.A \\ ${ }^{c}$ School of Accounting, Finance \& Economics, Edith Cowan University, Australia \\ Email: zhaoyong.zhang@ecu.edu.au
}

\begin{abstract}
When markets are assumed to be complete, option trading should not contain new information for market participants, as options derive their prices from the underlying stocks. However, if markets are incomplete, then this unidirectional relationship may not be true, because informed traders may prefer to trade options instead of the underlying stocks for several reasons: one, option trading involves lower transaction costs and higher financial leverage; and two, investors who have private information about stock price volatility can only make their bet on volatility in the option market. Compared with the research on the relationship between options trading activity and stock prices, there is little analysis on the information embodied in option transactions volume for stock market volatility, which undoubtedly is an important variable for risk management and portfolio allocation.
\end{abstract}

This study focuses on the dynamic linkages between option trading volume and stock market volatility. We compare the significance of option trading activity in explaining the volatilities of the underlying stocks with that of stock market volume by selecting 15 New York Stock Exchange (NYSE) stocks that are most actively traded in the option markets during the period from December 112002 to August 31 2006. Our approach implies the following two distinctive features:

- instead of the put/call volume ratio conventionally used in the literature, we measure the influence of option volume on stock market volatility by constructing the relative put (RPUT) and relative call (RCALL) ratios.

- our approach also allows us to quantify the impact of option volume on the existence of persistence and asymmetry in stock market volatility. Instead of the usual generalized autoregressive conditional heteroskedasticity $(\mathrm{GARCH})$ model that is commonly used to analyze the stock volume-volatility relation, we adopt Nelson's (1991) exponential GARCH (EGARCH) approach in this study.

For each stock, it is noted that the trading activities in the put and call options markets have significant explanatory power for stock market volatility. In addition, the results indicate that the call options trading activity has a stronger impact on stock volatility compared with that of the put options. Our results demonstrate that information and sentiment in the option market is useful for the estimation of stock market volatility. Also, the significance of the effects of option trading activity on stock price volatility is observed to be comparable to that of stock market trading activity. Furthermore, the persistence and asymmetric effects in the volatility of some stocks tend to disappear once option trading activity is taken into account.

Keywords: Information linkage, stock market volatility, option trading volume, asymmetric effects 


\section{INTRODUCTION}

The information embodied in the trading activity of option and stock markets is an interesting subject studied by many researchers. Assuming markets are complete, option trading should not contain new information for market participants, as options derive their prices from the underlying stocks. However, if markets are incomplete, then this unidirectional relationship may not be true, because informed traders may prefer to trade options instead of the underlying stocks for several reasons: one, option trading involves lower transaction costs and higher financial leverage; and two, investors who have private information about stock price volatility can only make their bet on volatility in the option market (see Chan et al., 2002). As such, the option trading process may not be redundant. Instead, it could play a significant role in price discovery and even contain information on stock market volatility.

The existing literature on whether the option market plays an important role in impounding information into stock prices presents rather mixed evidence. As noted by Amin and Lee (1997), a large proportion of long (or short) positions are initiated in the option market prior to earnings announcements on the underlying stock. Boluch and Chamberlain (1997) suggest that the option volume-stock price relationship is largely characterized by feedback, with option volume causing stock price changes. In contrast, Easley et al. (1998) provide evidence that stock price changes seem to lead option volumes, and there is "little or no evidence that put or call option volumes lead stock price changes". However, when they categorize option trades into positive-news and negative-news trades, they reject the hypothesis that option volumes contain no information about future stock price changes. More recently, Pan and Poteshman (2006) find strong evidence that equity option trading volume contains information about future stock price movements; stocks with relatively more new calls (puts) bought on them experience higher (lower) returns subsequently.

However, compared with the research on the relationship between options trading activity and stock prices, there is little analysis on the information embodied in option transactions volume for stock market volatility, which undoubtedly is an important variable for risk management and portfolio allocation. This is quite surprising, considering the fact that the option market is uniquely suited for trading on volatility information. Cherian and Weng (1999) empirically investigate the presence of volatility information trading in the option market and its implications for option bid-ask implied volatility spreads as predicted in a recent article by Cherian and Jarrow (1998). Their major finding is consistent with the prediction that there will be a positive correlation between option volume and bid-ask implied volatility spreads, given the presence of directional and volatility information traders. A recent paper by $\mathrm{Ni}$ et al.(2007) demonstrate that option volume is informative about future stock market volatility, because the net volatility demand for options is positively related to the subsequent volatility of underlying stocks.

This paper fills the gap in the literature by focusing on the dynamic linkages between option trading volume and stock market volatility. We compare the significance of option trading activity in explaining the volatilities of the underlying stocks with that of stock market volume by selecting 15 New York Stock Exchange (NYSE) stocks that are most actively traded in the option markets during the period from December 112002 to August 31 2006. Our approach implies the following two distinctive features. First, instead of the put/call volume ratio conventionally used in the literature, we measure the influence of option volume on stock market volatility by constructing the relative put (RPUT) and relative call (RCALL) ratios. The main advantages for this approach are: (1) we can determine the intensity of the option trading activity for a particular day relative to the past trading sessions, (2) the RPUT and RCALL ratios can be used to measure the degree of market sentiment, i.e., a high RPUT (RCALL) ratio may indicate that bearish (bullish) sentiment is comparatively strong, which allow us to address the question of whether relative peaks and valleys in call and put volumes reflect changes in information and sentiment that impact stock price volatility, and (3) since the relative put and call volume ratios are separately computed, it may be possible to distinguish the effects of bearish and bullish sentiments on stock market volatility (see Steenbarger, 2003 and 2006).

Second, our approach also allows us to quantify the impact of option volume on the existence of persistence and asymmetry in stock market volatility. Instead of the usual generalized autoregressive conditional heteroskedasticity $(\mathrm{GARCH})$ model that is commonly used to analyze the stock volume-volatility relation, we adopt Nelson's (1991) exponential GARCH (EGARCH) approach in this study. The EGARCH $(1,1)$ model places no restrictions on all the parameters, which makes the estimation process more tractable. The persistence of volatility shocks can also be meaningfully interpreted, as the model resembles the structure of a linear autoregressive model in logarithms. The EGARCH model also permits a certain degree of oscillatory 
behavior in the conditional variance as the persistence coefficient can be either positive or negative, and, unlike the symmetric GARCH model, asymmetric effects in volatility are incorporated in the EGARCH mode.

We find evidence that the RPUT and RCALL ratios are positively correlated with stock market volatility, thereby supporting our argument that the option trading process is not redundant and contains valuable information on stock market volatility. The results show that the impact of the trading activity of the call options market on stock volatility is relatively stronger than that of the put options market, and the significance of options trading activity in explaining the volatilities of the underlying stocks is comparable to that of stock trading activity. The persistence and asymmetric effects in the volatility of some stocks tend to disappear once option trading activity is taken into account. These finding lend additional support to our argument that options and stock markets are quite integrated, and has important implication for practitioners in the market and future research in this area.

The rest of the paper is organized as follows. Section 2 describes the methodology used for this study, and Section 3 analyzes the data sets and the estimation results. The last section concludes.

\section{METHODOLOGY AND THE MODEL}

It is well documented that the volatility of financial time series exhibits time-varying conditional heteroskedasticity, which is commonly modeled using the GARCH approach of Bollerslev (1986). Various hypotheses have been proposed to explain the stylized fact of GARCH effects in volatility, and one promising explanation suggests that daily stock returns are generated by a mixture of distributions (Andersen, 1996). According to the mixture-of-distributions hypothesis, the rate at which information arrives in the market can be viewed as a process generated by the stochastic mixing variable. If the daily number of information arrivals is positively correlated across days, then the model predicts serial correlation in the squared daily returns. The amount of information arrivals can be approximated by the daily trading activity in the stock market, and many researchers incorporate the effects of stock volume when they estimate the volatility of stock markets (see Lamoureux and Lastrapes, 1990; Gallagher and Kiely, 2005). According to Lamoureux and Lastrapes (1990), under the assumption that trading volume is the mixing variable, volume is weakly exogenous in the sense of Engle et al. (1983). Many of these papers typically use the GARCH model, which does not admit asymmetric effects in volatility and require non-negative constraints to be imposed on the parameters.

To circumvent the problems associated with the symmetric GARCH approach, we adopt Nelson's (1991) EGARCH model. In order to specify the EGARCH model, we begin by modeling the conditional mean equation for daily stock returns:

$$
\begin{aligned}
& r_{t}=\mu\left(r_{t-1}\right)+\varepsilon_{t} \\
& \varepsilon_{t} \mid \Phi_{t-1} \sim N\left(0, h_{t}\right)
\end{aligned}
$$

where $r_{t}$ represents the rate of return, $\mu\left(r_{t-1}\right)$ is the conditional mean function (which can be an autoregressive-moving average (ARMA) model), $\varepsilon_{t}$ is the random disturbance term that is normally distributed conditional on past information $\Phi_{t-1}$, and $h_{t}$ represents the conditional variance of stock market returns.

We then specify and estimate the following three conditional variance equations. The first one is set for stock market volatility without any trading activity:

$$
\log h_{t}=\omega+\beta_{1}\left|\frac{\varepsilon_{t-1}}{h_{t-1}}-\sqrt{\frac{2}{\pi}}\right|+\gamma \frac{\varepsilon_{t-1}}{h_{t-1}}+\beta_{2} \log h_{t-1}
$$

Equation (3) serves as the baseline model, as it does not involve any inclusion of the trading volumes of the option and stock markets. The parameter $\gamma$ measures the magnitude of asymmetry in volatility. If it is significantly different from zero, then asymmetric effects are present. The parameter $\beta_{2}$ measures the 
Ho et al., Modeling Information Linkages in the Stock and Options Markets

persistence of the logarithm of the lagged conditional variance term. A high value of $\beta_{2}$ indicates that volatility is persistent and shocks to volatility will take a longer period to dissipate.

The second conditional variance equation specifies the relationship between stock market volatility and option trading activity:

$$
\begin{aligned}
& \log h_{t}=\omega+\beta_{1}\left|\frac{\varepsilon_{t-1}}{h_{t-1}}-\sqrt{\frac{2}{\pi}}\right|+\gamma \frac{\varepsilon_{t-1}}{h_{t-1}}+\beta_{2} \log h_{t-1}+\beta_{3} \log R P U T_{t}+\beta_{4} \log R C A L L_{t} \\
& \operatorname{RPUT}_{t}=\frac{\text { Put volume at time } t}{\text { Mean of put volume in past } 60 \text { days }} \\
& \text { RCALL }_{t}=\frac{\text { Call volume at time } t}{\text { Mean of call volume in past } 60 \text { days }}
\end{aligned}
$$

As shown in equations (4)-(6), to incorporate the effects of options volume on stock return volatility, we construct the RPUT and the RCALL ratios and include them into the conditional variance equation. By dividing the put (call) volume with a "rolling window" average of the put (call) volume in the previous 60 trading days, it is possible to gauge whether the market is relatively bearish (bullish) for a particular day relative to the past. A priori, the signs and magnitudes of $\beta_{3}$ and $\beta_{4}$ cannot be determined. Even if the values are negative, the conditional variance is still guaranteed to be positive at any time. If $\beta_{3}<\beta_{4}$, then it implies that the call option volume has a greater impact on stock return volatility compared with the put option volume.

The third conditional variance equation assesses the effects of stock trading activity on stock market volatility, specified as follows:

$$
\log h_{t}=\omega+\beta_{1}\left|\frac{\varepsilon_{t-1}}{h_{t-1}}-\sqrt{\frac{2}{\pi}}\right|+\gamma \frac{\varepsilon_{t-1}}{h_{t-1}}+\beta_{2} \log h_{t-1}+\beta_{3} \log V_{t}
$$

where $V_{t}$ is the stock market volume. Equation (7) is similar to the stock volume-volatility specification used in previous papers, such as Lamoureux and Lastrapes (1990).

\section{EMPIRICAL ANALYSIS}

\subsection{Data Description}

The data sets comprise 15 New York Stock Exchange (NYSE) stocks that are most actively traded in the option markets, including AIG (American International Group), C (Citigroup), ELN (Elan Corp.), GM (General Motors), GS (Goldman Sachs Group), IBM (International Business Machine), MO (Altria Group), MRK (Merck \& Co.), MU (Micron Technology), NEM (Newmont Mining Corp.), PFE (Pfizer Inc), TXN (Texas Instruments), TYC (Tyco International), VLO (Valero Energy Corp.) and WMT (Wal-Mart Stores). We rank all the NYSE stocks based on the total put and call contracts volume of each stock for the period from December 112002 to August 31 2006. Stocks with actively traded options are most likely to have a sufficiently large number of daily information arrivals. Indeed, when we rank all the NYSE stocks based on the total stock market trading volume for the same period, several of the 15 stocks with the highest option volume are also the ones with the highest stock trading activity. The prices and trading volumes of the 15 stocks are obtained from the Center for Research in Security Prices (CRSP) database.

\subsection{Empirical Results}

We report in Table 1 the basic descriptive statistics of options and stock trading volumes of these 15 stocks. The results for the daily return series of these stocks are not reported but available upon request. Two observations deserve mention. First, all the return series are leptokurtic, which is a regularity highlighted by many researchers of empirical finance. Second, based on the BDS test proposed by Brock et al. (1996), most 
Ho et al., Modeling Information Linkages in the Stock and Options Markets

of the return series display highly nonlinear dependencies. The statistically significant BDS test statistics could indicate the presence of timevarying conditional heteroskedasticity. It is noted that the (mean) trading volume for call options is found on average higher than that for put options, which is consistent with Pan and Poteshman (2006). In addition, option trading volume is substantially smaller than stock trading volume. This finding is consistent with the well-known fact that the trading activity in the option market is only a tiny fraction of that in the underlying stock market.

The RPUT and the RCALL ratios for these stocks are calculated but not reported. It is found that in some cases, such as GM and MO, the RPUT and the RCALL ratios appear to evolve quite differently, with the RCALL reaching levels that are five to eight times higher than the RPUT at times. One possible explanation is that the trading activity is more intense for call options than for put options. This finding is actually consistent with that of Pan and Poteshman (2006). However, for some other stocks such as

\begin{tabular}{|c|c|c|c|c|c|}
\hline Stock & Variable & Mean & Median & Maximum & Minimum \\
\hline \multirow{3}{*}{ AIG } & CALLVOL & 8525.5296 & 5306 & 164460 & 180 \\
\hline & PUTVOL & 6957.7750 & 4063 & 324090 & 27 \\
\hline & VOL & 7283404.6620 & 6031900 & 70462400 & 963600 \\
\hline \multirow{3}{*}{ C } & CALLVOL & 20711.9139 & 12849 & 1247739 & 659 \\
\hline & PUTVOL & 12309.8579 & 9075 & 178804 & 297 \\
\hline & VOL & 13947530.8396 & 13321200 & 47819200 & 2420700 \\
\hline \multirow{3}{*}{ ELN } & CALLVOL & 15437.8850 & 8333 & 143939 & 85 \\
\hline & PUTVOL & 6831.9241 & 2962 & 147752 & 1 \\
\hline & $\mathrm{VOL}$ & 7370327.2451 & 4344950 & 167101400 & 624000 \\
\hline \multirow{3}{*}{ GM } & CALLVOL & 13098.4812 & 6124 & 510079 & 92 \\
\hline & PUTVOL & 15796.0226 & 7963 & 172597 & 98 \\
\hline & VOL & 8044624.1933 & 5960300 & 63733900 & 1084600 \\
\hline \multirow{3}{*}{ GS } & CALLVOL & 9378.7755 & 5044 & 1994686 & 86 \\
\hline & PUTVOL & 4900.7970 & 3963 & 46496 & 62 \\
\hline & $\mathrm{VOL}$ & 3888785.6574 & 3654700 & 15680600 & 796200 \\
\hline \multirow{3}{*}{ IBM } & CALLVOL & 15132.2505 & 11951 & 108286 & 1624 \\
\hline & PUTVOL & 11602.7570 & 8697 & 85424 & 775 \\
\hline & VOL & 6168959.9376 & 5649050 & 27932400 & 1408500 \\
\hline \multirow{3}{*}{ MO } & CALLVOL & 37800.5393 & 12734 & 3493782 & 382 \\
\hline & PUTVOL & 14911.4758 & 8827 & 206050 & 355 \\
\hline & VOL & 7620536.7955 & 6312300 & 52453800 & 1490400 \\
\hline \multirow{3}{*}{ MRK } & CALLVOL & 9751.3351 & 5454 & 396591 & 118 \\
\hline & PUTVOL & 6427.2888 & 3481.5 & 145292 & 155 \\
\hline & VOL & 9220376.1703 & 7325150 & 145038000 & 1892100 \\
\hline \multirow{3}{*}{ MU } & CALLVOL & 9464.0700 & 5640 & 165803 & 163 \\
\hline & PUTVOL & 4103.6997 & 2110 & 67218 & 19 \\
\hline & $\mathrm{VOL}$ & 9574606.6028 & 8676800 & 46225000 & 1978200 \\
\hline \multirow{3}{*}{ NEM } & CALLVOL & 12361.0774 & 8882.5 & 101158 & 354 \\
\hline & PUTVOL & 6455.9323 & 4347 & 43331 & 109 \\
\hline & VOL & 5576882.1979 & 5067200 & 20448600 & 1748700 \\
\hline \multirow{3}{*}{ PFE } & CALLVOL & 22480.0559 & 15269 & 290159 & 502 \\
\hline & PUTVOL & 14360.4189 & 8224 & 192559 & 679 \\
\hline & VOL & 24566756.2406 & 21593300 & 291494900 & 3898500 \\
\hline \multirow{3}{*}{ TXN } & CALLVOL & 11128.3677 & 8153.5 & 67856 & 502 \\
\hline & PUTVOL & 7270.4581 & 5351.5 & 56579 & 293 \\
\hline & $\mathrm{VOL}$ & 13076793.6237 & 12251900 & 51136200 & 1758500 \\
\hline \multirow{3}{*}{ TYC } & CALLVOL & 7708.1913 & 4351 & 144614 & 1 \\
\hline & PUTVOL & 4467.5283 & 2168.5 & 80229 & 1 \\
\hline & $\mathrm{VOL}$ & 10333781.3228 & 8391250 & 107856300 & 1678300 \\
\hline \multirow{3}{*}{ VLO } & CALLVOL & 10605.2306 & 3770 & 125904 & 9 \\
\hline & PUTVOL & 6168.5388 & 2476.5 & 63172 & 1 \\
\hline & VOL & 4819865.2252 & 2888250 & 36183200 & 167100 \\
\hline \multirow{3}{*}{ WMT } & CALLVOL & 10757.3922 & 7209.5 & 242729 & 516 \\
\hline & PUTVOL & 8467.1649 & 5134.5 & 124395 & 161 \\
\hline & VOL & 10823657.8502 & 9628650 & 96677100 & 3119300 \\
\hline
\end{tabular}
CALLVOL: Volume of call options, PUTVOL: Volume of put options, VOL: Stock market volume

AIG and PFE, RPUT is sometimes higher than RCALL. By comparing the RPUT and the RCALL of each stock with the corresponding put/call volume ratio, it is apparent that the RPUT and RCALL ratios highlight peaks in the option market trading activity that are visibly different from the put/call ratio. Furthermore, for the stocks AIG and GM, some of the peaks in the RPUT (RCALL) graphs are highly prominent, suggesting that market sentiment could be particularly bearish (bullish) for that specific day relative to the past 60 trading days. In contrast, by observing the graphs of put/call ratio for these two stocks, the peaks do not stand out very clearly. These graphical observations may suggest that the RPUT and RCALL ratios could capture changes in sentiment and information that may otherwise not be detected by the conventional put/call ratio.

We first estimate the baseline model specified in equation (3), and then the extended models specified in equations (4) and (7), respectively. The results for the baseline model (available upon request) show that the estimated values of the parameter $\beta_{2}$ for stocks including AIG, IBM, MO, MU, TYC and VLO are significantly positive and above 0.9 , indicating a high degree of volatility persistence. The $\gamma$ coefficient is found statistically significant with a negative sign for six stocks, including AIG, C, GM, IBM, MO and NEM, implying asymmetric effects in volatility for these stocks are present. The finding of asymmetric volatility has important implications. This is because negative shocks have a greater impact on future volatility levels compared with positive shocks of the same magnitude. This stylized fact is popularly known as the "leverage" effect (see Black, 1976). 
Ho et al., Modeling Information Linkages in the Stock and Options Markets

We report in Table 2 the estimation results for the relationship between stock market volatility and option trading activity associated with equation (4). One noteworthy finding is that the RPUT and RCALL ratios are significantly positively correlated with stock market volatility. For RPUT, the estimated values range from 0.0707 to 0.4680 , whereas for RCALL, the range is 0.06273 to 0.9949 , and many of these values are significant at the $1 \%$ level. It is interesting to note that, for all the stocks except GS, the estimated parameter of RCALL is usually larger than that of RPUT. The results seem to suggest that even though the option transactions embody

\begin{tabular}{|c|c|c|c|c|c|c|}
\hline Stock & $\omega$ & $\beta_{1}$ & $\gamma$ & $\beta_{2}$ & $\beta_{3}$ & $\beta_{4}$ \\
\hline AIG & $\begin{array}{l}0.323210^{\text {***** }} \\
(0.11)\end{array}$ & $\begin{array}{l}.375701 \text { **** } \\
(0.07)\end{array}$ & $\begin{array}{l}-0.022092 \\
(0.05)\end{array}$ & $\begin{array}{l}0.194284^{* * *} \\
(0.10)\end{array}$ & $\begin{array}{l}0.179852 * * \\
(0.10)\end{array}$ & $\begin{array}{l}.531202^{* * * *} \\
(0.10)\end{array}$ \\
\hline C & $\begin{array}{l}-0.13382^{* * * * * *} \\
(0.03)\end{array}$ & $\begin{array}{l}0.225981 \text { **** } \\
(0.04)\end{array}$ & $\begin{array}{l}-0.079047 \text { *** } \\
(0.03)\end{array}$ & $\begin{array}{l}0.924342 \\
(0.03)\end{array}$ & \begin{tabular}{|l|}
$0.070707 * *$ \\
$(0.04)$
\end{tabular} & \begin{tabular}{|l}
0.062730 ***** \\
$(0.03)$
\end{tabular} \\
\hline ELN & $\begin{array}{l}2.446787^{\text {***** }} \\
(0.51)\end{array}$ & 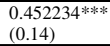 & $\begin{array}{l}0.016783 \\
(0.10) \\
\end{array}$ & $\begin{array}{l}0.056026 \\
(0.15)\end{array}$ & \begin{tabular}{|l|}
0.149526 \\
$(0.11)$ \\
\end{tabular} & \begin{tabular}{|l|}
0.994934 ***** \\
$(0.18)$ \\
\end{tabular} \\
\hline GM & $\begin{array}{l}1.361074^{* * * *} \\
(0.15)\end{array}$ & $\begin{array}{l}0.200714^{* * *} \\
(0.08)\end{array}$ & $\begin{array}{l}-0.003889 \\
(0.05)\end{array}$ & $\begin{array}{l}-0.041003 \\
(0.08)\end{array}$ & $\begin{array}{l}0.306911^{\text {***** }} \\
(0.09)\end{array}$ & $\begin{array}{l}0.697998^{\text {**** }} \\
(0.10)\end{array}$ \\
\hline GS & $\begin{array}{l}0.899707^{\text {**** }} \\
(0.10)\end{array}$ & $\begin{array}{l}0.041212 \\
(0.08)\end{array}$ & $\begin{array}{l}-0.061941 \\
(0.05)\end{array}$ & $\begin{array}{l}-0.306935^{* * *} \\
(0.15)\end{array}$ & $\begin{array}{l}0.468008^{\text {***** }} \\
(0.07)\end{array}$ & $\begin{array}{l}0.164493^{* * * *} \\
(0.06)\end{array}$ \\
\hline IBM & $\begin{array}{l}0.107486 \\
(0.08)\end{array}$ & $\begin{array}{l}0.136067^{*} \\
(0.08)\end{array}$ & $\begin{array}{l}-0.017391 \\
(0.05)\end{array}$ & $\begin{array}{l}-0.032976 \\
(0.08)\end{array}$ & $\begin{array}{l}0.186955 * * \\
(0.09)\end{array}$ & $\begin{array}{l}0.943168 \text { **** } \\
(0.12)\end{array}$ \\
\hline MO & $\begin{array}{l}0.599496^{\text {***** }} \\
(0.15)\end{array}$ & $\begin{array}{l}0.283254^{* * * *} \\
(0.10)\end{array}$ & $\begin{array}{l}-0.090427 \\
(0.06)\end{array}$ & $\begin{array}{l}0.031397 \\
(0.09)\end{array}$ & $\begin{array}{l}0.335891^{\text {****** }} \\
(0.09)\end{array}$ & $\begin{array}{l}0.500480^{* * * * *} \\
(0.06)\end{array}$ \\
\hline MRK & $\begin{array}{l}0.797319^{* * *} \\
(0.13)\end{array}$ & $\begin{array}{l}0.124250 \\
(0.08)\end{array}$ & $\begin{array}{l}-0.014803 \\
(0.05)\end{array}$ & $\begin{array}{l}-0.200323^{* * *} \\
(0.09)\end{array}$ & $\begin{array}{l}0.449809^{\text {**** }} \\
(0.09)\end{array}$ & $\begin{array}{l}0.462563^{* * * *} \\
(0.13)\end{array}$ \\
\hline $\mathrm{MU}$ & $\begin{array}{l}2.032779^{\text {**** }} \\
(0.22)\end{array}$ & $\begin{array}{l}0.047254 \\
(0.10)\end{array}$ & $\begin{array}{l}0.039700 \\
(0.06)\end{array}$ & $\begin{array}{l}-0.012301 \\
(0.15) \\
\end{array}$ & $\begin{array}{l}0.195264^{\text {**** }} \\
(0.05)\end{array}$ & $\begin{array}{l}0.441509^{\text {**** }} \\
(0.07)\end{array}$ \\
\hline NEM & $\begin{array}{l}\begin{array}{l}1.660247^{* * * * *} \\
(0.13)\end{array} \\
\end{array}$ & $\begin{array}{l}0.009313 \\
(0.07)\end{array}$ & $\begin{array}{l}-0.063271 \\
(0.06)\end{array}$ & $\begin{array}{l}-0.245401 \text { ***** } \\
(0.09)\end{array}$ & $\begin{array}{l}0.553518^{* * * * *} \\
(0.09)\end{array}$ & \begin{tabular}{|l|}
0.157590 \\
$(0.38)$ \\
\end{tabular} \\
\hline PFE & $\begin{array}{l}0.550164^{\text {**** }} \\
(0.11)\end{array}$ & $\begin{array}{l}0.206136 * * \\
(0.09)\end{array}$ & $\begin{array}{l}-0.118925 * \\
(0.07)\end{array}$ & $\begin{array}{l}-0.102148 \\
(0.09)\end{array}$ & $\begin{array}{l}0.273961 \text { **** } \\
(0.08)\end{array}$ & $\begin{array}{l}0.599665^{\text {**** }} \\
(0.10)\end{array}$ \\
\hline TXN & $\begin{array}{l}1.859013^{* * * *} \\
(0.17)\end{array}$ & $\begin{array}{l}-0.039753 \\
(0.08)\end{array}$ & $\begin{array}{l}-0.003290 \\
(0.05)\end{array}$ & $\begin{array}{l}-0.116306 \\
(0.11)\end{array}$ & $\begin{array}{l}0.235724 * * \\
(0.10)\end{array}$ & $\begin{array}{l}0.603753 \text { **** } \\
(0.16)\end{array}$ \\
\hline TYC & $\begin{array}{l}1.326850^{\text {**** }} \\
(0.19)\end{array}$ & $\begin{array}{l}0.189802^{*} \\
(0.10)\end{array}$ & $\begin{array}{l}0.033486 \\
(0.07)\end{array}$ & $\begin{array}{l}-0.223521 \\
(0.14)\end{array}$ & $\begin{array}{l}0.235135^{\text {**** }} \\
(0.07)\end{array}$ & $\begin{array}{l}0.370400^{\text {**** }} \\
(0.06)\end{array}$ \\
\hline VLO & $\begin{array}{l}1.823120^{\text {***** }} \\
(0.15)\end{array}$ & $\begin{array}{l}0.007902 \\
(0.09)\end{array}$ & $\begin{array}{l}-0.076672 \\
(0.06)\end{array}$ & $\begin{array}{l}-0.204001^{* * *} \\
(0.08)\end{array}$ & $\begin{array}{l}0.301433 \text { **** } \\
(0.07)\end{array}$ & \begin{tabular}{|l}
0.468329 **** \\
$(0.08)$
\end{tabular} \\
\hline WMT & $\begin{array}{l}0.271901^{\text {**** }} \\
(0.09)\end{array}$ & $\begin{array}{l}0.083591 \\
(0.07)\end{array}$ & $\begin{array}{l}-0.044523 \\
(0.05)\end{array}$ & $\begin{array}{l}-0.113909 \\
(0.08)\end{array}$ & $\begin{array}{l}0.242037^{* * * * *} \\
(0.05)\end{array}$ & $\begin{array}{l}0.616880^{\text {****** }} \\
(0.07)\end{array}$ \\
\hline
\end{tabular}
Note: ${ }^{*}$ indicates significant at the $10 \%$ level, $* *$ significant at the $5 \%$ level, and $* * * *$ significant at the $1 \%$ level. The figures in parenthesis are the Bollerslev-Wooldridge (1992) heteroskedastic-consistent standard errors.

information for stock market volatility, the impact of trading activity of call options on stock volatility is stronger than that of put options. This finding is apparently consistent with our earlier observation that the (mean) trading volume of call options is usually higher than that of put options. It is also interesting to note that, once RPUT and RCALL are incorporated in the variance equation, the degree of volatility persistence is reduced significantly for some of the stocks, such as AIG, C, GM, IBM, MO and MU. Some possible explanations for the reduction in volatility persistence may be due to the "information processing hypothesis" proposed by Engle et al. (1990), the correlated public information and news arrivals (see Kalev et al., 2004 and Janssen, 2004), and the heterogeneous beliefs for option volumes.

Table 3 reports the estimation results by taking account of the effects of stock trading activity on stock market volatility. As we expected, it is found that the stock transactions volume has significant explanatory power for the volatility of stock markets, with a value ranging from 1.006 for VLO to 2.44 for IBM. Similar to the results for the option trading activity, almost all the estimated values of the parameter for stock volume are significantly positive. It is also found that the volatility persistence has been reduced, and asymmetric effects have become insignificant in all the cases. These findings lend further support to our argument that the trading

\begin{tabular}{|c|c|c|c|c|c|}
\hline Stock & $\omega$ & $\beta_{1}$ & $\gamma$ & $\beta_{2}$ & $\beta_{3}$ \\
\hline$\overline{\mathrm{AIG}}$ & $\begin{array}{l}-31.74997 * * * * \\
(2.01)\end{array}$ & $\begin{array}{l}0.205476^{* * *} \\
(0.09)\end{array}$ & $\begin{array}{l}-0.010726 \\
(0.06)\end{array}$ & $\begin{array}{l}-0.299294 * * * \\
(0.07)\end{array}$ & $\begin{array}{l}2.047486^{* * * *} \\
(0.13)\end{array}$ \\
\hline $\mathrm{C}$ & $\begin{array}{l}-0.130720 \\
(0.12)\end{array}$ & $\begin{array}{l}-0.014297 \text { ** } \\
(0.01)\end{array}$ & $\begin{array}{l}-0.018862 \\
(0.01)\end{array}$ & $\begin{array}{l}0.998221 \\
(0.001)\end{array}$ & $\begin{array}{l}0.008544 \\
(0.01)\end{array}$ \\
\hline ELN & $\begin{array}{l}-18.53891 \text { **** } \\
(1.60)\end{array}$ & $\begin{array}{l}0.433039 * * * \\
(0.11)\end{array}$ & $\begin{array}{l}0.059537 \\
(0.08)\end{array}$ & $\begin{array}{l}-0.311061 * * * \\
(0.07)\end{array}$ & $\begin{array}{l}1.391757^{* * * *} \\
(0.10)\end{array}$ \\
\hline GM & $\begin{array}{l}-30.06190^{* * * *} \\
(1.72)\end{array}$ & $\begin{array}{l}0.102405 \\
(0.08) \\
\end{array}$ & $\begin{array}{l}0.014770 \\
(0.05)\end{array}$ & $\begin{array}{l}-0.271143 * * * \\
(0.05)\end{array}$ & $\begin{array}{l}1.980649 \text { **** } \\
(0.11)\end{array}$ \\
\hline GS & $\begin{array}{l}-34.76293 * * * * \\
(1.89)\end{array}$ & $\begin{array}{l}-0.063075 \\
(0.08)\end{array}$ & $\begin{array}{l}0.016215 \\
(0.04)\end{array}$ & $\begin{array}{l}-0.422298 * * * \\
(0.06)\end{array}$ & $\begin{array}{l}2.342064^{* * * *} \\
(0.12)\end{array}$ \\
\hline IBM & $\begin{array}{l}-38.13306 * * * * \\
(3.57)\end{array}$ & $\begin{array}{l}-0.094620 \\
(0.09)\end{array}$ & $\begin{array}{l}-0.015538 \\
(0.05)\end{array}$ & $\begin{array}{l}-0.190508 \\
(0.08)\end{array}$ & $\begin{array}{l}2.439989 \text { **** } \\
(0.23)\end{array}$ \\
\hline MO & $\begin{array}{l}-32.70715^{* * * *} \\
(3.01)\end{array}$ & $\begin{array}{l}0.027043 \\
(0.08)\end{array}$ & $\begin{array}{l}-0.028036 \\
(0.04)\end{array}$ & $\begin{array}{l}-0.104622 \\
(0.06)\end{array}$ & $\begin{array}{l}2.079144 \text { *** } \\
(0.19)\end{array}$ \\
\hline MRK & $\begin{array}{l}-28.78867 * * * \\
(1.86)\end{array}$ & $\begin{array}{l}0.137856 \\
(0.09)\end{array}$ & $\begin{array}{l}-0.006772 \\
(0.05)\end{array}$ & $\begin{array}{l}-0.374345 * * * \\
(0.06)\end{array}$ & $\begin{array}{l}1.833188^{* * *} \\
(0.12)\end{array}$ \\
\hline$\overline{\mathrm{MU}}$ & $\begin{array}{l}-30.93248^{* * * *} \\
(1.98)\end{array}$ & $\begin{array}{l}0.122778 \\
(0.08)\end{array}$ & $\begin{array}{l}0.080206 \\
(0.05)\end{array}$ & $\begin{array}{l}-0.366453 * * * \\
(0.06)\end{array}$ & $\begin{array}{l}2.060658 \text { **** } \\
(0.12)\end{array}$ \\
\hline NEM & $\begin{array}{l}-33.50369^{* * * * *} \\
(2.45)\end{array}$ & $\begin{array}{l}0.021438 \\
(0.10)\end{array}$ & $\begin{array}{l}-0.085531 \\
(0.06)\end{array}$ & $\begin{array}{l}-0.415016^{* * * *} \\
(0.05)\end{array}$ & $\begin{array}{l}2.266965^{* * * *} \\
(0.16)\end{array}$ \\
\hline PFE & $\begin{array}{l}-30.57111 \text { **** } \\
(2.35)\end{array}$ & $\begin{array}{l}0.166952^{* *} \\
(0.08)\end{array}$ & $\begin{array}{l}-0.024834 \\
(0.05)\end{array}$ & $\begin{array}{l}-0.366397 * * * \\
(0.08)\end{array}$ & $\begin{array}{l}1.828608 * * * * \\
(0.14)\end{array}$ \\
\hline TXN & $\begin{array}{l}-36.38416 \text { *** } \\
(2.41)\end{array}$ & $\begin{array}{l}-0.013903 \\
(0.08)\end{array}$ & $\begin{array}{l}0.017843 \\
(0.05)\end{array}$ & $\begin{array}{l}-0.337452 \text { **** } \\
(0.06)\end{array}$ & $\begin{array}{l}2.335176^{* * * *} \\
(0.15)\end{array}$ \\
\hline TYC & $\begin{array}{l}-27.81395^{\text {*** }} \\
(1.56)\end{array}$ & $\begin{array}{l}0.014307 \\
(0.09)\end{array}$ & $\begin{array}{l}0.025037 \\
(0.05)\end{array}$ & $\begin{array}{l}-0.254081 * * \\
(0.06)\end{array}$ & $\begin{array}{l}1.789464 * * * \\
(0.10)\end{array}$ \\
\hline VLO & $\begin{array}{l}-12.93729 * * * * \\
(1.12)\end{array}$ & $\begin{array}{l}0.073922 \\
(0.09) \\
\end{array}$ & $\begin{array}{l}-0.019865 \\
(0.05)\end{array}$ & $\begin{array}{l}-0.618101^{* * * *} \\
(0.07)\end{array}$ & $\begin{array}{l}1.005483^{* * * *} \\
(0.07)\end{array}$ \\
\hline WMT & $\begin{array}{l}-24.58357 * * * * \\
(2.18)\end{array}$ & $\begin{array}{l}0.072645 \\
(0.12)\end{array}$ & $\begin{array}{l}-0.015540 \\
(0.06)\end{array}$ & $\begin{array}{l}-0.425736^{* * * *} \\
(0.09)\end{array}$ & $\begin{array}{l}1.533026 * * * * \\
(0.14)\end{array}$ \\
\hline
\end{tabular}

Note: * indicates significant at the $10 \%$ level, ${ }^{* *}$ significant at the $5 \%$ level, and $* * *$ significant at the $1 \%$ level. The figures in parenthesis are the Bollerslev-Wooldridge (1992) heteroskedastic-consistent standard errors. activities in the put and call options markets have significant explanatory power for stock market volatility, while the persistence and asymmetric effects in the stock volatility tend to disappear once option trading activity is taken into account.

\section{CONCLUDING REMARKS}

Although it is recognized that traders with private information on stock market volatility can only make their bets in the option markets and that option markets are uniquely suited for volatility information trading, there is little research that quantifies the impact of option volume on the volatilities of the underlying stocks. In this paper, we analyze the information embodied in option trading activity for stock market volatility. In particular, we have constructed two option volume ratios that are different from the conventional put/call volume ratio 
and employed the EGARCH approach to analyze the information in option trading activity for stock market volatility, using a sample of 15 stocks with the highest option trading volume from the New York Stock Exchange. We find strong evidence that the RPUT and RCALL ratios are positively correlated with stock market volatility, and the impact of the trading activity of the call options market on stock volatility is relatively stronger than that of the put options market. Our results demonstrate that information and sentiment in the option market is useful for the estimation of stock market volatility. It is also found that the persistence and asymmetric effects in the volatility of some stocks tend to disappear once option trading activity is taken into account. These finding lend further support to our argument that options and stock markets are quite integrated, and has important implication for practitioners in the market and future research in this area.

There are many promising directions and extensions that can be pursued. First, we have not examined in greater detail why call option volume has a greater impact on stock market volatility as compared with put option volume. Also, another extension is to investigate how the predictive ability of options volume on stock volatility differs across options contracts with changes in the degree of moneyness and time-to-expiration. One other issue that deserves attention is the factors affecting the dynamics of the options volume. Is option volume influenced by the proportion of informed traders in the options markets? If this is true, then what are the implications for stock market volatility? Furthermore, it would be interesting to model the dynamic timevarying correlations between option volume and stock market volatility using a multivariate volatility framework. The relationship between implied volatility, option volume, and stock volatility is also another noteworthy area of research. We leave these topics to future research.

\section{REFERENCES}

Amin, K, and C Lee (1997), "Option Trading, Price Discovery, and Earnings News Dissemination", Contemporary Accounting Research 14 (1997): 153-192.

Black, Fischer, "Studies in Stock Price Volatility Changes", Proceedings of the Business and Economics Statistics Section American Statistical Association (1976): 177-181.

Bollerslev, T, "Generalized Autoregressive Conditional Heteroskedasticity", Journal of Econometrics 31 (1986): 307-327.

Bollerslev, T, and J Wooldridge, "Quasi-maximum likelihood estimation and inference in dynamic models with time-varying covariances" Econometric Reviews 11.2 (1992): 143-172.

Boluch, M, and T Chamberlain, "Option Volume and Stock Price Behavior: Some Evidence from the Chicago Board Options Exchange”, Atlantic Economic Journal 25.4 (1997): 358-370.

Brock W, J. Scheinkman W. Dechert and LeBaron, "A test for independence based on the correlation dimension”, Econometric Reviews 15.3 (1996): 197-235.

Cherian, J, and R Jarrow, “Options Markets, Self-Fulfilling Prophecies, and Implied Volatilities", Review of Derivatives Research 2 (1998): 5-37.

Cherian, J, and W Weng, "An Empirical Analysis of Directional and Volatility Trading in Options Markets", Journal of Derivatives 7.2 (1999): 53-65.

Engle, R, D Hendry, and J Richard, "Exogeneity”, Econometrica 51 (1983): 277-304.

Engle, R, T Ito, and W Lin, "Meteor Showers or Heat Waves? Heteroskedastic Intra-Daily Volatility in the Foreign Exchange Market", Econometrica 58.3 (1990): 525-542.

Gallagher, L and D Kiely, "Volume and GARCH Effects for Dual-Listed Equities: Evidence from Irish Equities", The Irish Accounting Review 12 (2005): 63-82.

Janssen "Public information arrival and volatility persistence in financial markets", European Journal of Finance 10.3 (2004): 177-197.

Kalev, P, W Liu, P Pham and E Jarnecic, "Public Information Arrival and Volatility of Intraday Stock Returns", Journal of Banking and Finance 28 (2004):1441-1467.

Lamoureux, C, and W Lastrapes, "Heteroskedasticity in Stock Return Data: Volume versus GARCH Effects”, Journal of Finance 45.1 (1990): 221-229.

Nelson, D, "Conditional Heteroskedasticity in Asset Returns: a New Approach", Econometrica 59.2 (1991): 347-370.

Ni, S, J Pan, and A Poteshman, "Volatility Information Trading in the Option Market", MIT Sloan School of Management Working Paper March 2007.

Pan, J, and Poteshman, "The Information in Option Volume for Future Stock Prices", Review of Financial Studies 19.3 (2006): 871-908.

Steenbarger, B, The Psychology of Trading, Wiley: 2003.

Steenbarger, B, Enhancing Trader Performance, Wiley: 2006. 